\title{
Artikel
}

\section{Op de kast en weer terug, maar niet in de la}

\author{
Raad van State en kabinet over de keuze tussen de twee bestraffende stelsels in het \\ publiekrechtelijke sanctierecht
}

Mr. dr. A.R. Hartmann en mr. dr. O.J.D.M.L. Jansen*

Meer dan vijf jaar geleden, op Prinsjesdag 14 september 2015, werd het advies van de Afdeling advisering van de Raad van State bekend dat op 13 juli 2015 aan de (toenmalige) minister van Veiligheid en Justitie werd uitgebracht. ${ }^{1}$ Deze bekendmaking werd destijds door deze afdeling van de Raad van State gemarkeerd met een persbericht met de ronkende titel: 'Meer andacht nodig voor rechtsbescherming burger bij bestuurlijke boetes'. ${ }^{2}$ Het kritische advies werd ongevraagd uitgebracht en dat kwam (en komt) niet veel voor. De positie van de justitiabele stond in dat advies centraal en met persbericht en handelwijze wekte de Afdeling advisering de sterke (politieke) indruk dat er heel wat aan de hand was met de rechtsbescherming in het boeterecht.

Zoals we hierna nog nader zullen toelichten, verdient dat advies ook nu nog een forse dot tegengas, en niet alleen van de regering. De regering gaf dat tegengas al in een eerste reactie van de regering op 8 januari $2016 .{ }^{3}$ De

* Mr. dr. A.R. Hartmann is senior raadsheer bij de sector Strafrecht in het gerechtshof 's-Hertogenbosch en voormalig bijzonder hoogleraar Bestuursstrafrecht aan de Erasmus Universiteit Rotterdam. Mr. dr. O.J.D.M.L. Jansen is advocaat bestuursrecht bij van Ardenne \& Crince le Roy Advocaten, voormalig bijzonder hoogleraar Europees bestuursrecht en openbaar bestuur aan de Universiteit Maastricht, guest senior lecturer Comparative and Global Administrative Law aan de Tilburg University en international visiting scholar aan de American University, Washington D.C. College of Law (AUWCL). Voor beide auteurs geldt dat de inhoud geheel op persoonlijke titel is geschreven.

1. Advies van de Afdeling advisering van de Raad van State aan de Minister van Veiligheid en Justitie inzake sanctiestelsels, Stcrt. 14 september 2015, nr. 30280.

2. Zie www.raadvanstate.nl/pers/persberichten/tekstpersbericht.html?id= 774\&summary_only=\&category_id=8.

3. Kamerstukken 2015/16, 34300 VI, nr. 72. op meer onderzoek gebaseerde reactie van de regering, het nader rapport, werd bijna drie jaar na de datum waarop het advies werd uitgebracht, te weten op 14 mei 2018, aangeboden. Ook in de literatuur werd er al terechte kritiek geuit op het advies van de Afdeling advisering. ${ }^{4}$ Zo schreef Bröring terecht, nadat hij de punten van verschil tussen bestuursrechtelijke en strafrechtelijke handhaving met bestraffende sancties kort had samengevat:

'Inderdaad zijn dat allemaal punten van verschil. Ik onderschrijf echter niet de suggestie die van het advies uitgaat dat het bestuursrecht op deze punten in het algemeen uit een oogpunt van rechtswaarborgen onderdoet voor het strafrecht.'

Het gehele bestraffende publiekrecht, of dat nu in het strafrecht of juist in het bestuursrecht is vormgegeven, valt onder dezelfde waarborgen en rechtsbeschermingsstandaarden van met name artikel 6 EVRM en (bij de implementatie van het unierecht) artikel 47 Handvest. ${ }^{5}$ De Awb-wetgever heeft in de boeteregeling waarborgen ingebouwd die beogen recht te doen aan die standaard. Ook heeft hij er daarbij uitdrukkelijk voor gekozen zoveel mogelijk aansluiting te zoeken bij het strafrecht,

4. Zie onder andere: A. Mein \& B. van der Vorm, 'Het Nader rapport bestuurlijke boetestelsels: een stap terug in duidelijkheid?', JV 2018, p. 37-48; en R. de Rijck, 'Enkele opmerkingen over het kabinetsstandpunt bestuurs- en strafrecht, ook in het licht van het Sorgdrager-rapport', JB-plus 2018/4

5. Dat strafrechtelijke waarborgen gelden voor bestuurlijke boetes is overigens niet in elke rechtstaat het uitgangspunt. Dat bestaat weliswaar voor de Europese Unie en Raad van Europa, maar bijvoorbeeld niet in de Verenigde Staten. 
zodat nodeloze verschillen worden voorkomen. ${ }^{6}$ In dat licht bezien, ligt het uiteraard niet voor de hand dat het met de rechtswaarborgen en rechtsbescherming in het bestuursrecht slechter is gesteld dan in het strafrecht. ${ }^{7}$

En ja, de bestuurlijke boete werkt veelal goed en heeft meerwaarde. De Afdeling advisering schrijft immers terecht:

\begin{abstract}
'De bestuurlijke boete heeft zich bemezen als een efficiënt handhavingsinstrument en heeft de punitieve handhaving van het ordeningsrecht op een hoger plan gebracht. (...) De professionaliteit en sectorale expertise van bestuursorganen belast met de handhaving van ordeningswetgeving zorgen voor een snelle afhandeling van boetezaken en de pakkans merkt afschrikkend. De wijze maarop de bestuursrechtelijke procedure is ingericht-ook die in het geval van punitieve sancties zoals de bestuurlijke boetemaakt een lik-op-stuk beleid bij handhaving met aanzienlijke efficiencyvoordelen mogelijk.' (p. 3/4)
\end{abstract}

en:

\begin{abstract}
'Deze afstemming van beide stelsels op elkaar hoeft echter niet te betekenen dat de ontwikkeling van het punitieve bestuursrecht naar de bestuursrechtelijke beboeting van naar aard en feitencomplex minder eenvoudige feiten wordt teruggedraaid, maardoor het punitieve bestuursrecht zich opnieum zou beperken tot de veelvoorkomende, relatief eenvoudige en lichte feiten. Het bestuursrecht heeft zich op veel terreinen van ordeningsmetgeving bemezen en een terugkeer naar de situatie van begin jaren negentig is niet realistisch.' (p. 8).
\end{abstract}

Het gaat bij de verschillen die de Afdeling opsomt en die volgens haar de reden waren om de noodklok van het ongevraagde advies te luiden, in de kern genomen eigenlijk om niet meer dan klein fruit. Wij zullen dat in het hiernavolgende toelichten. Het advies getuigt niet alleen van de onjuiste gedachte dat het bestuursrecht uit een oogpunt van rechtswaarborgen tekortschiet in vergelijking met het strafrecht. Ook pleit de Afdeling voor verzwaring van de rechtsbescherming in het bestraffende bestuursrecht zonder dat duidelijk wordt wat daaronder moet worden verstaan.

Wij hadden ons nu juist kunnen voorstellen dat er meer aandacht zou zijn geweest in een advies over dit onderwerp voor thema's zoals het (belastend) getuigenbewijs in het bestraffend bestuursrecht, het wetgevingsbeleid waarin zowel beboetbare als strafbare feiten meer en meer stapelen en de wetgeving die op bepaalde terreinen grote spanning veroorzaakt met de eisen aan de kenbaarheid van zowel het beboetbare als het strafbare feit. We zullen hierna laten zien dat het optuigen van de rechtsbescherming en rechtswaarborgen de positie van de justitiabele in de praktijk juist negatief kan beïnloeden, omdat de kosten om zijn gelijk te halen met het door-

6. Kamerstukken // 2003/04, 29 702, nr. 3, p. 125

7. We wijzen erop dat de Afdeling de term 'rechtsbescherming' hanteert waar steeds rechtswaarborgen zijn bedoeld. lopen van een zienswijze-, bezwaar-, beroeps- en hogerberoepsprocedure enorm toenemen. ${ }^{8}$ Ook kan daarmee de uitvoerbaarheid in het gedrang komen. ${ }^{9}$ Uiteindelijk zal het hier gaan om een verstandige keuze om recht te doen aan evenredigheid in procedurele rechtswaarborgen.

Het voorgaande neemt niet weg dat de Afdeling advisering terecht op een aantal punten de vinger op de zere plek legt. Met het introduceren van de strafbeschikking in het strafrecht hebben regering en wetgever zich in een lastig parket gebracht waarin een keuze tussen het bestuursrechtelijk of strafrechtelijk bestraffend moeilijker te motiveren valt. De totstandkomingsgeschiedenis van de Omgevingswet laat dat overtuigend zien. ${ }^{10} \mathrm{De}$ strafbeschikking moet nu eenmaal worden beschouwd als een bestuursrechtelijke bevoegdheid in handen van justitiële bestuursorganen. ${ }^{11}$ Ook wees de Afdeling advisering terecht op de tekortschietende eenheid van wetgeving waarin de hoogte van de bestuurlijke boete wordt bepaald en afgestemd op de geldboetecategorieën uit het strafrecht. De wetgever had al bij de totstandkoming van de Awb-boeteregeling (en de daarbij behorende aanpassingswetgeving) kunnen en moeten kiezen voor een algemene bepaling waarin de geldboetecategorieën van overeenkomstige toepassing worden verklaard. ${ }^{12}$

Bedacht moet worden dat de Afdeling advisering zich vooral richt tot de wetgever en zijn boetewetgevingsbeleid, en niet tot de rechter die in het boeterecht een zeer belangrijke rol heeft genomen om rechtsbescherming te bieden en rechtswaarborgen af te dwingen. Tussen wetgeving en rechtspraak zitten de tot boeteoplegging bevoegde bestuursorganen die een verstandig boetebeleid dienen te voeren, maar dat niet altijd doen. Een dergelijke uitvoering in de praktijk kan door wetgeving niet in concreto worden voorkomen. Een belangrijke - in deze bijdrage overigens niet nader besproken - speler is

8. Hierbij denken we bijvoorbeeld aan de praktijk bij de stevige bestuurlijke boetes opgelegd door de I-SZW.

9. De bestuurlijke boete die kan worden opgelegd voor 'overlast-feiten' op grond van de Gemeentewet is daarvan een goed voorbeeld.

10. Zie onder meer kamerstukken II 2013/14, 33 962, 3, p. 48, 243-244 en 385; kamerstukken I/ 2013/14, 33 962, nr. 4, p. 128-129; kamerstukken II 2015/16, 33 962, nr. 185, met name p. 5-7; B.F. Keulen, H.E. Bröring e.a., De punitieve handhaving van de Omgevingswet, Zutphen: Uitgeverij Paris 2015; A.B. Blomberg, 'Aanvullend advies Punitieve handhaving Omgevingswet', www.omgevingsportaal.nl; O.J.D.M.L. Jansen, 'Op naar een algemene boetebevoegdheid in de Omgevingswet', TO 2015, afl. 4, p. 165-173 en O.J.D.M.L. Jansen, 'Appels en peren. Bestraffende handhaving in de Omgevingswet', VGR 2016, p. 65 e.v.

11. Zie reeds O.J.D.M.L. Jansen, 'De dynamiek van het publiekrechtelijke sanctierecht. Enkele beschouwingen over het bestraffende deel daarvan', NJV-preadvies, in: J. de Hullu e.a., Herziening van het sanctiestelsel, Deventer: Kluwer 2002, p. 167-255, met name p. 250 en 252; alsmede O.J.D.M.L. Jansen \& W.G.A. Hazewindus, 'Inleiding: de bestuurlijke boete in de derde tranche!', in: W.H.A. Hazewindus \& O.J.D.M.L. Jansen (red.), Van Boeteatelier tot boetefabriek, Deventer: Kluwer 1995, p. 4 en 13.

12. Zie reeds O.J.D.M.L. Jansen, 'De dynamiek van het publiekrechtelijke sanctierecht. Enkele beschouwingen over het bestraffende deel daarvan', NJV-preadvies, in: J. de Hullu e.a., Herziening van het sanctiestelsel, Deventer: Kluwer 2002, p. 167-255, i.h.b. p. 230-232. 
hier toch ook de politiek die in bepaalde periodes op bepaalde beleidsterreinen in wetgeving en instructies aan uitvoerende bestuursorganen een boeteflinkheid tentoonspreidde die de rechter dwong aan de noodrem te trekken. De Sociale zekerheidswetgeving is daarbij steeds de hoek waar de klappen vallen. Eerst was het de op 1 augustus 1996 in werking getreden Wet boeten, maatregelen en terug- en invordering sociale zekerheid ${ }^{13}$ en vervolgens - en in nog veel sterkere mate - de op 1 januari 2013 in werking getreden Wet aanscherping handhaving en sanctiebeleid SZW-wetgeving. ${ }^{14}$ Dat zijn weliswaar belangrijke, maar niet de enige voorbeelden.

Wij zien een ontwikkeling in drie lijnen die zich al wat langer voordoet: (1) het ontlasten van het strafrechtsysteem om veel voorkomende, massale overtredingen beter te kunnen handhaven, (2) het op- en uitbouwen van forse sanctiebevoegdheden voor niet-justitiële bestuursorganen bij de regulering van markten en ondernemingen en ten slotte, (3) het uitbouwen van openbare orde-bevoegdheden en preventieve handhavingsbevoegdheden van bestuursorganen (met name burgermeesters) ter ondersteuning van de strafrechtelijke handhaving. We beperken ons hier tot de eerste twee ontwikkelingslijnen. ${ }^{15}$

Hierna zullen we eerst in grote lijnen de ontwikkeling van boetebevoegdheden en wetgeving daarover schetsen. Vervolgens bespreken we het advies van de Afdeling advisering van de Raad van State. Daarna bespre-

ken we een aantal wetswijzigingen die naar ons oordeel noodzakelijk zijn en tot slot komen we tot een afronding.

\section{Ontwikkeling van boeteregelgeving, de ontlasting van het strafrecht en de versterking van het bestuursrecht}

Sinds ongeveer de jaren zeventig werd de noodzaak om het overbelaste en overvraagde strafrecht te ontlasten steeds groter. Daarbij werd niet alleen de strafprocedure gewijzigd met maatregelen zoals de introductie van de transactiebevoegdheid en de geleidelijke uitbreiding van de mogelijkheden om van de unus-rechtspraak gebruik

13. Wet boeten, maatregelen en terug- en invordering sociale zekerheid, Stb. 1996, 248 en Stb. 1996, 295. Zie ook de parlementaire geschiedenis onder kamerstuknummer 23909

14. Wet aanscherping handhaving en sanctiebeleid SZW-wetgeving, Stb. 2012, 462 en Stb. 2012, 498. Zie ook de parlementaire geschiedenis onder kamerstuknummer 33207

15. Zie voor de derde ontwikkelingslijn op het vlak van het publiekrechtelijke sanctierecht met name: M.A.D.W. de Jong, 'De burgemeester als misdaadbestrijder: reddingsboei of dwaallicht?', preadvies VAR nr. 138, Den Haag 2007, p. 59-119; H.J.B. Sackers, Herder, hoeder, en handhaver. De burgemeester en het bestuurlijk sanctierecht (oratie Nijmegen), Nijmegen 2010 en B. van der Vorm, 'De straffende burgemeester: een gevaar voor het strafrecht?', DD 2017/9, p. 77-91. te maken. ${ }^{16}$ Er werd ook gezocht naar mogelijkheden buiten het strafprocesrecht. Al ver voor de inwerkingtreding van de Algemene wet bestuursrecht werden de mogelijkheden van bestuursorganen om te handhaven uitgebreid. Het ging anvankelijk vooral om nietbestraffende mogelijkheden. De snelle opmars van de last onder dwangsom van de toenmalige Hinderwet naar de rol van algemene en populaire herstelsanctie in het algemeen bestuursrecht is daarvan een illustratie. ${ }^{17}$

De jaren tachtig zijn van groot belang voor de vormgeving van het huidige publiekrechtelijke sanctierecht. We wijzen op de NJV-preadviezen van Corstens en Schaffmeister uit $1984,{ }^{18}$ het Öztürk-arrest van 21 februari $1984^{19}$ en de daaropvolgende rechtspraak van de belastingkamer van de Hoge Raad over de fiscale verhogingen/boetes, het voorstel van de Commissie vereenvoudigde afdoening lichte overtredingen van verkeersvoorschriften van 29 mei $1985^{20}$ dat aan de Wet administratiefrechtelijke handhaving van verkeersvoorschriften (Wet Mulder) ${ }^{21}$ ten grondslag lag, en het advies van de Wetenschappelijke Raad uit $1988 .^{22}$ De emancipatie van het bestuursrecht als rechtsgebied raakte in die periode in een stroomversnelling door de uitbreiding van de grondwettelijke codificatieopdracht met algemene regels van bestuursrecht in de Grondwet van 1983, de instelling van de Commissie wetgeving algemene regels van bestuursrecht (de commissie-Scheltema) en het eerste deel van het Voorontwerp Algemene wet bestuursrecht ${ }^{23}$ waarin een hoofdstuk over handhaving was gereserveerd.

In de jaren negentig werd veel aandacht besteed aan het 'handhavingstekort'. Het gaat daarbij om beleidsstukken als 'Recht in beweging', 24 'Zicht op wetgeving', 25 en 'Met vaste hand'. ${ }^{26}$ De Commissie Bestuursrechtelijke en Privaatrechtelijke Handhaving (Commissie-Michiels) onderzocht dit tekort en omschreef het als: 'wanneer bij niet-naleving een tot handhaving bevoegde instantie

16. In 1973 deed de commissie partiële herziening strafvordering het voorstel een wettelijke regeling van het executoir-verklaren van transacties in te voeren.

17. Zie daarover bijvoorbeeld J.H. Verweij, De bestuurlijke dwangsom, Deventer: W.E.J. Tjeenk Willink 1997, p 11 e.v.

18. G.J.M. Corstens, 'Civielrechtelijke, administratiefrechtelijke of strafrechtelijke rechtshandhaving?', (preadvies), HNJV-I, Zwolle 1984, p. 1-128 en D. Schaffmeister, 'Politiële en justitiële delicten', (preadvies), HNJV-I, Zwolle 1984, p. 131-291.

19. EHRM 21 februari 1984, Publ. ECHR, Series A Vol. 73/NJ 1988, 937 (Öztürk).

20. Rapport van de Commissie vereenvoudigde afdoening lichte overtredingen van verkeersvoorschriften, 's-Gravenhage, mei 1985.

21. Wet van 3 juli 1989, Stb. 1989, 300, houdende administratiefrechtelijke afdoening van inbreuken op bepaalde verkeersvoorschriften. De WAHV is over een periode van 2 jaar vanaf 1 september 1990 fasegewijs ingevoerd. Zie Kamerstukken I/ 1987/88, 20 329, nr. 3.

22. Wetenschappelijke Raad voor het Regeringsbeleid, Rechtshandhaving, rapport nr. 35, 's-Gravenhage 1988.

23. Voorontwerp Algemene wet bestuursrecht, Eerste deel, Commissie wetgeving algemene regels van bestuursrecht, 's-Gravenhage: Staatsuitgeverij 1987.

24. Recht in beweging, Kamerstukken I/ 1990/91, 21 829, nr. 1-2.

25. Zicht op wetgeving, Kamerstukken I/ 1990/91, 22 008, nr. 1-2.

26. Met vaste hand, Kamerstukken I/ 1990/91, 22 045, nr. 1-2 
rechtens moet handhaven doch hetzij wel wil, maar niet kan handhaven, hetzij wel kan, maar niet wil handhaven; "het" handhavingstekort is dan de optelsom van alle tekorten tezamen. ${ }^{27}$ In de genoemde justitiële beleidsstukken heeft het handhavingstekort tot gevolg dat tot verbetering van de handhaving van regels wordt opgeroepen. Daarbij wordt gesteld dat verbetering van met name ordenings- of instrumentele beleidswetgeving niet meer kan worden bereikt door eenzijdig op de strafrechtelijke handhaving te leunen. Gezocht zal moeten worden naar een evenwichtiger verdeling van de handhavingslasten tussen bestuur en justitie. De optiek is dat naast de rijksoverheid medeoverheden een eigen verantwoordelijkheid hebben voor de handhaving van rechtsregels. $^{28}$

Voor de strafrechtelijke handhaving heeft dit tot gevolg dat een keuze voor het strafrecht in het algemeen slechts valt te rechtvaardigen indien aannemelijk wordt gemaakt dat privaatrechtelijke, bestuursrechtelijke en tuchtrechtelijke oplossingen tekortschieten. ${ }^{29}$ Belangrijke afwegingen in de jaren negentig zijn daarbij de massaliteit van regelschendingen, de notie dat het strafrecht vaak niet het effectiefste middel is en het besef dat een slagvaardige rechtshandhaving in het strafrecht wordt belemmerd door een te ver doorgeschoten stelsel van rechtsbeschermingsvoorzieningen. ${ }^{30}$ Het strafrecht dient bij de zogenoemde instrumentele beleidswetgeving, in aansluiting op preventieve maatregelen en nietstrafrechtelijke handhavingssystemen, zo veel mogelijk een reservefunctie te hebben, hetgeen betekent dat het strafrecht primair zal worden ingezet voor meer ernstige inbreuken op regels die elementaire belangen beschermen. ${ }^{31}$ De bestuurlijke boete wordt verondersteld niet alleen een passende aanvulling te zijn op de bestaande mogelijkheden van herstelsancties, maar ook een in vergelijking met de strafrechtelijke afdoening een effectieve en efficiënte mogelijkheid om door middel van een likop-stukbestraffing direct op te treden.

Op 12 januari 1994 werd het belangrijke advies 'Handhaving door bestuurlijke boeten' van de Regeringscommissie voor de toetsing van wetgevingsprojecten aan de Minister van Justitie aangeboden. ${ }^{32}$ Aan deze commissie werd gevraagd om de wenselijkheid en de mogelijkheid te onderzoeken om op grotere schaal dan tot dan toe het geval was de bestuurlijke boete in te zetten naast of in plaats van strafrechtelijke handhaving. Ook werd deze commissie gevraagd om aanbevelingen te doen over de wijze waarop een en ander wettelijke zou moeten worden vormgegeven. Omdat deze vraag betrekking kon

27. Vgl. Commissie Bestuursrechtelijke en Privaatrechtelijke Handhaving (Commissie-Michiels), Handhaven op niveau, Deventer: Tjeenk Willink 1998, p. 36.

28. Strafvordering in balans 1993, p. 23-24

29. Recht in beweging 1990, p. 40.

30. Strafvordering in balans 1993, p. 20; De taken van justitie 1993, p. 7.

31. Met vaste hand 1990, p. 17.

32. Commissie voor de toetsing van wetgevingsprojecten (CTW), Handhaving door bestuurlijke boeten, Advies aan de minister, Den Haag 12 januari 1994. hebben op alle bestuursrechtelijke wetgeving, beperkte de commissie zich tot de wetgeving waarop de Wet op de economische delicten van toepassing was. Op het moment dat het advies werd uitgebracht bestond er al een aantal boeteregelingen, ook regelingen waar stevige bestuurlijke boetes konden worden opgelegd. ${ }^{33}$ Het ging destijds om boetebevoegdheden in de Mediawet, de Wet op de telecommunicatievoorzieningen, de Wet individuele huursubsidie, de fiscale boete en uiteraard ook de Wet Mulder. Er werd op dat moment al gedacht of gewerkt aan het algeheel herzien van het fiscale boetestelsel, een conceptwetsvoorstel bestuurlijke boete in de visserij, de introductie van de bestuurlijke boete in het sociale zekerheidsrecht (de latere Wet BMTI), het milieurecht, het mededingingsrecht, de Wet persoonsregistraties, en aan de Awb-boeteregeling.

De commissie ontwikkelde criteria aan de hand waarvan bepaald kan worden of strafrechtelijke, dan wel bestuursrechtelijke handhaving de voorkeur verdient. Het is daarbij van belang dat de commissie aangaf dat de criteria die bij de Wet Mulder een rol speelden, niet alle relevant zijn en dat het EHRM ook bestuurlijke boetes voor zwaardere overtredingen aanvaardbaar achtte. Het voorgaande geeft al aan dat de bedoeling van de bestuurlijke boete niet uitsluitend was om als niet al te zware sanctie bij relatief eenvoudig te constateren overtredingen te dienen, maar stellig ook als stevige (hoge) sanctie bij minder eenvoudig te constateren overtredingen. De Afdeling advisering wijst er terecht op dat dat de realiteit van het wetgevingsbeleid is. ${ }^{34}$ De bevoegdheid om hoge bestuurlijke boetes op te leggen voor overtredingen die niet steeds eenvoudig zijn vast te stellen werd vooral bij gespecialiseerde bestuursorganen neergelegd. Op de poging van de Toetsingscommissie (en in navolging de regering) om criteria te ontwikkelen voor de introductie van de bestuurlijke boete zijn nog opmerkelijk veel (namelijk drie) nieuwe pogingen gevolgd. ${ }^{35}$ En op elk daarvan viel steeds wel wat af te dingen...

Anders gezegd: de Wet administratiefrechtelijke handhaving verkeersvoorschriften (de WAHV of Wet Mulder) en de redenen waarom verkeersovertredingen beboetbaar werden gesteld, zijn altijd een buitenbeentje

33. En laten we vooral niet vergeten dat het bestuursrecht op dit punt als voorbeeld diende voor de geldboete in het strafrecht. Zie J. van der Poel, Rondom compositie en compromis, Utrecht 1942, p. 265 en Van Wijk, Konijnenbelt \& Van Male, Hoofdstukken van Bestuursrecht, $16^{\mathrm{e}}$ druk, Deventer 2014, p. 478

34. We doelen op de volgende passage uit het rapport (p.1): 'Het meest in het oog springt het feit dat tegenwoordig - anders dan oorspronkelijk de bedoeling van de bestuurlijke boete was - zware, complexe overtredingen bedreigd worden met hoge bestuurlijke boetes, en dat hoge boetes worden gesteld op relatief lichte feiten.'

35. Het gaat om de notitie 'De keuze tussen sanctiestelsels en de betekenis van het Wetsvoorstel OM-afdoening daarvoor', van 8 november 2005 (Kamerstukken II 2005/06, 29 849, nr. 30); de Kabinetsnota over de uitgangspunten bij de keuze van een sanctiestelsel (Kamerstukken II 2008/09, 31700 VI, nr. 69) en de aanvulling van 17 december 2012 op die twee kabinetsnota's in de reactie van de regering op het rapport 'Referentiekader geldboetes' (Kamerstukken II 2012/13, 33400 VI, nr. 80). 
geweest. ${ }^{36}$ In 1995 schreef Wattel dat de criteria van de Toetsingscommissie tot de conclusie zouden leiden 'dat het enige bestuurlijke boetesysteem dat al heel lang en op zeer grote schaal werkt, namelijk het fiscale boetestelsel, juist niet zou behoren te bestaan.' En evenzeer terecht voegde hij daaraan toe:

\section{'Moeilijke constateerbaarheid van de overtreding kan overigens ook juist een reden vóór bestuurlijke hand- having zijn indien de te handhaven petgeving zó inge- mikkeld en omvangrijk is dat er voor het openbaar minis- terie en de gemone rechter niet aan te beginnen valt. ${ }^{37}$}

De door de regering onderschreven ${ }^{38}$ vaststelling van de commissie 'dat invoering van de bestuurlijke boete op grotere schaal een belangrijke bijdrage kan leveren aan de verbetering van de handhaving van de bestuursrechtelijke wetgeving' leidde uiteindelijk tot een grote toename van het aantal boetebevoegdheden in wetgeving. ${ }^{39}$ Het voorlopige eindresultaat is dat op dit moment de bestuurlijke boete al een aantal jaren een bestraffende sanctie is die tot het algemeen bestuursrecht behoort. Op een aantal beleidsterreinen valt verdere uitbreiding te verwachten zodat deze bestraffende sanctie ook daar als basisspeler kan worden opgesteld. ${ }^{40}$

De bestuurlijke boete is zo in de afgelopen decennia langs twee ontwikkelingslijnen tot wasdom gekomen. Op bijna elk beleidsterrein werden de bestaande mogelijkheden van bestuursorganen om bestuursdwang toe te passen, een last onder dwangsom op te leggen of een vergunning in te trekken, aangevuld met de mogelijkheid om een bestuurlijke boete op te leggen. Veelal bleef de mogelijkheid van justitiële bestraffing daarnaast bestaan. In een veel kleinere hoeveelheid gevallen - en dat is de tweede ontwikkelingslijn - werd de straf-

36. Net zoals dat het geval is met het Duitse voorbeeld van het Gesetz über Ordnungswidrigkeiten is de Wet Mulder zowel afwijkend bestuursrecht (met minder rechtswaarborgen en rechtsbescherming dan in het reguliere bestuursrecht, en flinke afwijkingen van de Awb) als afwijkend strafrecht.

37. P.J. Wattel, 'Enige opmerkingen over de bestuurlijke boete, mede uit fiscale hoek', in: W.G.A. Hazewindus \& O.J.D.M.L. Jansen (red.), Van boeteatelier tot boetefabriek, Deventer: Kluwer 1995, p. 165-183, met name p. 171. Hij verwees daarbij overigens naar het kabinetsstandpunt volgend op het rapport van de Toetsingscommissie en de opmerking daarin over de aanstaande mededingingsboete (Kamerstukken II 1993/94, 23400 VI, nr. 48, p. 22).

38. Het gaat om het regeringsstandpunt van 1 juli 1994 (Kamerstukken II 1993/94, 23400 VI, nr. 48).

39. Zie het overzicht in O.J.D.M.L. Jansen, 'Bestuurlijk en justitieel bestraffen in Nederland - op zoek naar (nog) meer eenheid', in: R.C. van Houten (red.), Economisch strafrecht en bestuurlijke boete. Themadag KESA 2010, Nijmegen: Wolf Legal Publishers 2011/12, p. 21-79 en 153-178. Het overzicht is alweer gedateerd: het aantal boeteregelingen is sindsdien alleen nog maar toegenomen.

40. Het gaat daarbij niet alleen om de Omgevingswet, maar ook om een algemene bevoegdheid voor decentrale overheden. Zie daarover onder meer: O.J.D.M.L. Jansen, 'Op naar een algemene boetebevoegdheid in de Omgevingswet', Tijdschrift voor Omgevingsrecht 2015, p. 165-173, A.B. Blomberg, 'De opmars van de bestuurlijke boete in het omgevingsrecht', Tijdschrift voor Omgevingsrecht 2017, p. 82-89; O.J.D.M.L. Jansen, 'Handhaving door de andere overheid. Een pleidooi voor aanpassing van de algemene regeling van gemeentelijke handhavingsbevoegdheden in de Gemeentewet', Gst. 7426 (2015), p. 472-480. rechtelijke handhaving vervangen door bestuursrechtelijke handhaving met de bestuurlijke boete. De meest in het oog springende voorbeelden daarvan zijn de zojuist genoemde WAHV en de Mededingingswet.

Na de Eerste en Tweede tranche (1 januari 1994) en de Derde tranche (1 januari 1998) trad op 1 juli 2009 de Vierde tranche van de Algemene wet bestuursrecht in werking. ${ }^{41}$ Onderdeel daarvan is de aanvulling van het hoofdstuk over bestuursrechtelijke handhaving met algemene bepalingen over thema's zoals het overtrederbegrip, het legaliteitsbeginsel en het zwijgrecht en een algemene regeling over de bestuurlijke boete. Deze laatste regeling is van toepassing indien de bijzondere wetgever een boetebevoegdheid regelt. De inhoud daarvan kan worden herleid tot de rechtspraak van de belastingkamer van de Hoge Raad, waarin vanaf $1985^{42}$ het systeem in de Algemene wet inzake rijksbelastingen stukje bij beetje werd herbouwd ${ }^{43}$ en de daaropvolgende zoektocht van bijzondere wetgevers naar de goede boeteregeling. Met de Vierde tranche Awb en de bijbehorende aanpassingswetgeving werden de boeteregelingen in de bijzondere wetgeving geharmoniseerd. ${ }^{44}$ Algemene daarin gemeenschappelijke elementen en rechtspraak daarover werden gecodificeerd. Uitgangspunt van de wetgever is dat het bestraffende bestuursrecht (het bestuursstrafrecht) niet nodeloos moet afwijken van het strafrecht en daarvan, gelet op artikel 6 EVRM, op een aantal punten ook niet kan afwijken. ${ }^{45} \mathrm{Op}$ een groot aantal essentiële punten wordt dan ook uitdrukkelijk aansluiting gezocht bij het eigenlijke strafrecht. ${ }^{46}$

Bestuurlijke boetes kunnen inmiddels op grond van meer dan 150 formeelwettelijke regelingen worden toegepast en er zijn dienaangaande nog verschillende wetsvoorstellen aanhangig bij de Eerste en Tweede Kamer. ${ }^{47}$ Enkele recente voorbeelden zijn, op het moment van schrijven van deze bijdrage, de bestuurlijke boete die

41. Wet van 25 juni 2009, Stb. 2009, 264 (Vierde tranche Awb), iwtr. 1 juli 2009. Zie hierover het Besluit van 25 juni 2009, Stb. 266.

42. Sinds HR 19 juni 1985, NJ 1986, 104.

43. Zie daarover bijvoorbeeld P.J. Wattel, 'Enige opmerkingen over de bestuurlijke boete, mede uit fiscale hoek', in: W.G.A. Hazewindus \& O.J.D.M.L. Jansen (red.), Van boeteatelier tot boetefabriek, Deventer: Kluwer 1995, p. 165-183, met name p. 166

44. Er werd al sinds ongeveer 1994 aan een algemene boeteregeling gewerkt, en het voorontwerp Vierde tranche Awb werd op 7 september 1999 aan de minister van Justitie aangeboden. De boeteregelingen in bijzondere wetgeving werden al daarop afgestemd.

45. Kamerstukken // 2003/04, 29 702, nr. 3, p. 125.

46. Zie hierover uitgebreid: L.J.J. Rogier, 'De Vierde Tranche Algemene wet bestuursrecht. Twee magische lijnen verschoven', NJB 2009, p. 1560-1566; F.C.M.A. Michiels, 'Bestraffende bestuurlijke handhaving onder de Awb-IV', Trema 2009, p. 282-288; en R. Stijnen, Rechtsbescherming tegen bestraffing in het strafrecht en het bestuursrecht, Deventer: Kluwer 2011, p. 517-707; O.J.D.M.L. Jansen, 'Bestuurlijk en justitieel bestraffen in Nederland - op zoek naar (nog) meer eenheid', in: R.C. van Houten (red.), a.w., p. 34 e.v.

47. Zie voor een overzicht uit het begin van deze ontwikkeling: D. Otto 'Schema boeteregelingen', in: H. de Doelder, M.E. de Meijer \& D. Otto (red.), De bestuurlijke boete in perspectief, Deventer: Gouda Quint 1999, p. 175-181 en Kamerstukken // 2003/04, 29 702, nr. 3, bijlage 2 (Wetsvoorstel Awb Vierde tranche). Zie ook O.J.D.M.L. Jansen, 'Bestuurlijk en justitieel bestraffen in Nederland - op zoek naar (nog) meer eenheid', in: R.C. van Houten (red.), a.w., p. 21-79, 153-178. 
aan de Wet luchtvaart wordt toegevoegd om slotmisbruik op gecoördineerde luchthavens te bestraffen (Kamerstukken 35 469) en het voorstel van Wet oneerlijke handelspraktijken landbouw- en voedselvoorzieningsketen (Kamerstukken 35 642). ${ }^{48}$

Het algemene beeld is nu dat in wetgeving waar de bestuurlijke boete een algemene bestuurlijke sanctie is, bij de handhaving van bedrijfsmatige activiteiten veelal drie mogelijkheden zijn opgenomen bij de afgrenzing van de strafrechtelijke en de bestuursrechtelijke sanctionering. Een eerste groep overtredingen kan uitsluitend bestuursrechtelijk worden bestraft met een bestuurlijke boete, een tweede, beperkte, groep wordt uitsluitend strafrechtelijk bestraft en een derde groep bestaat veelal uit overtredingen die niet alleen als beboetbaar feit worden aangewezen, maar ook als strafbaar feit.

Ten slotte merken wij op dat de overheveling van strafrechtelijke handhaving naar bestuursrechtelijke handhaving door middel van een bestuurlijke boete aansluitend binnen het strafrechtelijk kader een soort 'tegenbeweging' op gang heeft gebracht, waarbij allerlei ideeën werden geopperd om de strafrechtelijke afdoening doelmatiger te maken. Als reactie op de explosieve uitbreiding van de bestuurlijke boete, en met name op het dreigende gevaar van honderden gemeenten (waarmee het Openbaar Ministerie zijn bevoegdheidsuitoefening zou moeten afstemmen) met een boetebevoegdheid voor overlastfeiten, en ter leniging van de overbelasting, is in het strafrecht in 2008 de strafbeschikking geintroduceerd, waarbij volgens de kamerstukken een centrale ambitie is het vergroten van de veiligheid door vergroting van de doelmatigheid van de strafrechtelijke buitengerechtelijke afdoening. Hiermee is feitelijk een vorm van (hoofdzakelijk) bestuurlijke beboeting in het strafrecht geintroduceerd. ${ }^{49}$

Daarmee lijkt een duidelijke convergentie tussen het bestuursrecht en het strafrecht als sanctiestelsel plaats te vinden waarbij de overeenkomsten meer en meer de overhand lijken te nemen en verschillen tussen beide sanctiestelsels meer en meer op de achtergrond verdwijnen. ${ }^{50}$ Echter, de ontwikkeling van de laatste jaren op

48. Ook het voorstel tot Wijziging van de Wet toezicht en geschillenbeslechting collectieve beheersorganisaties auteurs- en naburige rechten (Kamerstukken 35 317) op grond waarvan het verval van de boetebevoegdheid wordt geregeld bij een bindende toezegging (voorgesteld artikel 17a) is vermeldenswaard.

49. Wet van 7 juli 2006, Stb. 2006, 330 (Wet OM-afdoening), inwtr. per 1 februari 2008. Zie Besluit van 21 december 2007, Stb. 2008, 4. Zie voor de kamerstukken inzake de strafbeschikking: Kamerstukken II 2004/05, 29 849, nr. 2 t/m Kamerstukken I 2005/06, 29849 (en 30 163), G. Zie voor de achtergrond van de strafbeschikking: A.R. Hartmann, 'De strafbeschikking: naar nieuwe grenzen van buitengerechtelijke afdoening binnen het strafrecht', Tijdschrift voor S\&O 2012, nr. 2, p. 58-64. Zie ook O.J.D.M.L. Jansen, ‘De dynamiek van het publiekrechtelijke sanctierecht. Enkele beschouwingen over het bestraffende deel daarvan', NJV-preadvies, in: J. de Hullu e.a., a.w.

50. Vgl. A.R. Hartmann, Over de grenzen van de dogmatiek en into fuzzy law (oratie Rotterdam), Apeldoorn/Antwerpen: Maklu 2011. Zie over verschillen en overeenkomsten tussen het strafrecht en het bestuursrecht reeds L.J.J. Rogier \& A.R. Hartmann, 'Verschillen en overeenkomsten tussen strafrecht en bestuursrecht', DD 1993, p. 1042-1058; het gebied van de bestuurlijke boete geeft een beeld te zien waarbij de hoogte van de mogelijk op te leggen bestuurlijke boetes enorm is toegenomen. Zo werden in korte tijd de hoogtes van de bestuurlijke boetes op het gebied van de sociale zekerheidswetgeving en daaropvolgend die mogelijk op te leggen door de Autoriteit Consument en Markt en de Autoriteit Financiële Markten fors verhoogd en kreeg de nieuw ingestelde Autoriteit Persoonsgegevens de mogelijkheid om eveneens torenhoge boetes op te leggen. ${ }^{51}$ Het is met name dit opmerkelijke verschil in de hoogte van de boete tussen de bestuurlijke boete en die zoals in de regel opgelegd in het strafrecht ${ }^{52}$ dat de aanzet heeft gevormd om recent de ontwikkeling van de bestuurlijke boete ter discussie te stellen. ${ }^{53}$ Zo discussieerde de VAR in haar jaarvergadering in 2014 aan de hand van preadviezen over bestuurlijke bestraffende sancties. ${ }^{54}$ In datzelfde jaar verscheen een uitgebreide studie naar aanleiding van de agenda van de rechtspraak 2011-2014 door de landelijke overleggen bestuursrecht en strafrecht inzake de adequate rechtsbescherming bij grondrechtenbeperkend overheidsingrijpen, waarbij een vergelijk werd gemaakt met het strafrecht voor onder andere de bestuurlijke boete. ${ }^{55}$

\section{Het advies van de Afdeling advisering en de reactie van de}

\section{regering}

Drie jaar voordat de Afdeling advisering haar advies uitbracht, had de regering in haar reactie op het rapport 'Referentiekader geldboetes' erkend dat er meer eenheid wenselijk was in de hoogte van geldboetes op het terrein van het strafrecht en het bestuursrecht. Voor de bepaling van de (maximum)hoogte van bestuurlijke boetes in wetgeving zou voortaan worden aangesloten bij de boe-

en O.J.D.M.L. Jansen, 'Bestuursrecht en strafprocesrecht: doorwerken of afgrenzen', in: T. Hoogenboom \& L.J.A. Damen (red.), In de sfeer van administratief recht (Konijnenbelt-bundel), Utrecht: Lemma 1994, p. 257-263.

51. Vgl. G.A. Biezeveld en A. Mein, 'Moet de opmars van de bestuurlijke boete worden gestuit?', Tijdschrift voor Toezicht 2015, p. 64; en A. Mein, De boete uit Balans, Het gebruik van de bestuurlijke boete in de praktijk van het financieel toezicht (diss. Rotterdam), Den Haag: Boom Lemma uitgevers 2015.

52. Opgemerkt zij dat in het economisch strafrecht net als in het economisch en financieel bestuursrecht ook al enige tijd forse omzetgerelateerde geldboetes mogelijk zijn.

53. Eerder waren reeds bezwaren geformuleerd tegen de hoogte van de boetes door L.F.M. Verhey \& N. Verheij, 'De macht van de marktmeesters. Marktoezicht in constitutioneel perspectief', preadvies Toezicht, Handelingen NJV 2005-1, Deventer 2005, p. 135-332, i.h.b. p. 258, 273, 289-292 en 327. Vgl. de reactie hierop van A.R. Hartmann, ‘Referentie bij preadvies', in: Toezicht, Handelingen NJV 2005-2, Deventer 2006, p. 36-39.

54. M. Batting, J. Heinrich \& R. Veldhuis, 'Boetes en andere bestraffende sancties: VAR-preadviezen 2014'

55. T. Barkhuysen e.a. (red.), Adequate rechtsbescherming bij grondrechten beperkend overheidsingrijpen, Kluwer 2014 
tecategorieën van artikel $23 \mathrm{Sr}^{56}$ Daarbij werd ook gewezen op het omzetgerelateerde maximum dat nu in artikel 23, lid $7 \mathrm{Sr}$ is neergelegd. Een jaar voorafgaand aan dat advies van de Afdeling advisering werd in het onderzoek door T. Barkhuysen en anderen naar de rechtsbescherming bij grondrechtenbeperkend overheidsingrijpen het invoeren van schorsende werking van bezwaar en (hoger) beroep tegen boetebesluiten aanbevolen, ${ }^{57}$ met de kanttekening:

'De metgever kan in de bijzondere met de schorsende merking beperken tot een nader te bepalen fase van de procedure, tot boetes boven een nader te bepalen bedrag, zekerheidsstelling verlangen, en een mettelijke rentebepaling opnemen. ${ }^{58}$

Op 13 juli 2015 komt de Afdeling advisering met haar advies, en daarin analyseert zij onder andere de verschillen tussen de bestuurlijke boete en het strafrecht, waarbij de strafbeschikking nadrukkelijk wordt betrokken. Daarbij wordt het vergelijk met name vanuit het oogpunt van de rechtsbescherming en rechtspositie van burgers en bedrijven benaderd. De Afdeling ziet de bestuurlijke boete als een belangrijke en niet weg te denken bestuurlijke sanctie, maar ziet daarbij wel niet te rechtvaardigen verschillen tussen beide wijzen van afdoening. De Afdeling adviseert concreet om het bestuursrecht en het strafrecht op elkaar af te stemmen door, waar nodig, de rechtsbescherming in het bestuursrecht gedeeltelijk te verzwaren. In dit geheel is volgens de Afdeling de rechtsbescherming van de burger onderbelicht geraakt. Dit advies is gegrond op twee constateringen.

In de eerste plaats worden steeds vaker zware en complexe overtredingen bedreigd met hoge bestuurlijke boetes en worden soms hoge boetes gesteld op relatief lichte feiten. Dit terwijl het strafrecht door invoering van de strafbeschikking ook mogelijkheden biedt. De bestuurlijke boete en de strafbeschikking zijn vergelijkbaar als sanctiemogelijkheid, maar de rechtsbescherming voor beide instrumenten is niet op vergelijkbare wijze geregeld. Ten aanzien van de hoogte van de bestuurlijke boetes stelt de Afdeling dat de minister van Justitie en Veiligheid meer de regie moet nemen bij het (beter) op elkaar afstemmen van de hoogte van de boetes voor dezelfde of soortgelijke overtredingen, zowel binnen het bestuursrecht als in vergelijking met het strafrecht door meer eenheid te brengen in de uitgangspunten voor de vaststelling van de hoogte van bestuurlijke boetes. Ver-

56. Deze aansluiting bij de geldboetecategorieën in artikel $23 \mathrm{Sr}$ had wat ons betreft allang in artikel 5:46 Awb opgenomen moeten zijn.

57. We wijzen erop dat in dit rapport ook (p. 181) aan de rechter werd aanbevolen om te bepalen dat wilsafhankelijk materiaal niet mag worden gebruikt voor maatregelen gericht op bestraffing, indien dat met een toezichtvordering (onder dwang) wordt of werd verkregen. Dat is inmiddels na een uitspraak van de Grote Kamer vaste rechtspraak die wat ons betreft in artikel 5:10a Awb zou moeten worden gecodificeerd.

58. T. Barkhuysen e.a. (red.), a.w., p. 182. schillende pogingen daartoe zijn in de afgelopen jaren onvoldoende sturend gebleken. ${ }^{59}$

In de tweede plaats merkt de Afdeling op dat de wetgever de keuze voor het punitieve bestuursrecht op basis van de meest recente criteria voor de keuze van een sanctiestelsel (de 'open' en 'besloten' context) snel maakt uit een oogpunt van efficiency, terwijl de wetgever onvoldoende rekening houdt met de gevolgen van de keuze voor de justitiabele wat zijn rechtsbescherming en de rechtspositie betreft. Hierbij merkt de Afdeling advisering op dat ook de strafrechtelijke handhaving niet heeft stilgezeten met de introductie van de strafbeschikking als mogelijkheid voor buitengerechtelijke afdoening van strafbare feiten. De discussie over de verschillen tussen strafrechtelijke handhaving en het punitieve bestuursrecht en de vraag naar de verhouding tussen beide stelsels, speelt al langer en breder. Zo heeft de vraag welke criteria zouden moeten gelden bij de keuze voor het ene dan wel voor het andere handhavingsinstrument bij het opstellen van nieuwe wetgeving inmiddels al wel tot diverse kabinetsnota's geleid maar (nog) niet tot het gezochte algemeen aanvaarde onderscheidende criterium.

De Afdeling advisering herhaalt haar stelling regelmatig dat er volgens haar opnieuw moet worden gekeken naar het niveau van de wettelijk geregelde rechtsbescherming bij bestraffende sancties en dat deze in het punitieve bestuursrecht zou moeten worden verzwaard. Nergens maakt ze echter concreet wat ze daarbij voor ogen heeft. Het blijft bij niet veel meer dan: 'Het is in de eerste plaats aan de wetgever om daarin concrete inhoudelijke keuzes te maken.' (p. 8). Juist ook omdat de rechtsbescherming in het bestuursrecht toereikend is, is het advies op dit punt niet overtuigend.

Bij vrijwel alle wettelijke regelingen waarin de bevoegdheid is neergelegd om stevige bestuurlijke boetes op te leggen, is al een zeer stevige procedure geregeld. $\mathrm{Na}$ het toezichtbezoek waarin beboetbare gedragingen zouden zijn vastgesteld, volgen - als niet eerst informeel gelegenheid wordt geboden op bepaalde verklaringen of het boeterapport te reageren - achtereenvolgens de zienswijzeprocedure (het horen), de bezwaarschriftprocedure, de beroepsprocedure en het hoger beroep. Vanaf de bezwaarschriftfase kan bovendien een voorlopige voorzieningsprocedure worden gestart om het uitstel van betaling of de betalingsregeling af te dwingen waartoe het bestuursorgaan niet uit zichzelf bereid is.
59. Verwezen wordt naar de kabinetsreactie op Groningse rapport Referentiekader geldboetes (Kamerstukken II 2012/13, 33400 VI, nr. 80) (Nota keuze sanctiestelsel 2012); de Boetewijzer voor het bepalen van de maximumboete in wetgeving (de Boetewijzer) opgenomen in het Integraal Afwegingskader voor beleid en regelgeving (IAK) dat richtsnoeren bevat voor het bepalen van nieuwe wettelijke maximale boetehoogtes en de totstandkoming van Aanwijzing 5.43 van de Aanwijzingen voor de regelgeving. Zie ook Kamerstukken II 2015/16, 34 429, nr. 4 en Kamerstukken I/ 2015/16, 34 412, nr. 4, p. 6-7. In het laatste geval gaat het om een kritisch advies van de Afdeling advisering over de verhoging van de bestuurlijke boete van $€ 405$ naar $€ 820.000$. 
Dat is al een grote stapeling van rechtsbescherming. In de praktijk bestaat echter niet zelden het gevoel dat er meerdere overbodige en vergeefse (de zienswijze wordt weggeschreven en het bezwaarschrift onder herstel van motivering ongegrond verklaard) rondjes rond de kerk nodig zijn voordat eindelijk gehoor bij de rechter kan worden (en niet zelden wordt) gevonden. De belanghebbende wordt daarmee op hoge kosten gejaagd van onder meer de rechtsbijstand die - hoewel niet verplicht vaak noodzakelijk is om effectief verweer te voeren. Moet de rechtsbescherming dan nog zwaarder? Welnee.

De verschillen in rechtsbescherming die de Afdeling advisering wél vermeldt, zijn wat ons betreft - met uitzondering van de schorsende werking van bezwaar en beroep - klein grut. Bovendien valt de vergelijking veelal in het nadeel van het strafrecht uit (bijvoorbeeld de hoorplicht en de beroepstermijn). Dat in het bestuursrechtelijke boeterecht wél griffierecht dient te worden voldaan en in het strafrecht niet, is naar wij menen meestal geen wezenlijke aantasting van de rechtsbeschermingsmogelijkheden van de boeteling. En mocht dat in een concreet geval anders zijn, dan kan de rechter op grond van het grondrecht op toegang tot de rechter corrigeren.

Dat het boetewetgevingsbeleid in werkelijkheid het introduceren van boetebevoegdheden niet beperkte tot eenvoudig constateerbare overtredingen en beperkte bestuurlijke boetes, is een volkomen terechte constatering door de Afdeling advisering. Dat de keuze voor het te volgen sanctiestelsel geen gemakkelijke afweging is, is al decennialang helder. We wezen al op de pogingen om bruikbare criteria te ontwikkelen. Begin 1994 adviseerde de Commissie van de Toetsing van Wetgevingsprojecten in haar advies 'Handhaving door bestuurlijke boeten' om de bestuurlijke boete in te voeren in een groot aantal wetten op het terrein van het economisch ordeningsrecht. ${ }^{60}$ Een half jaar na het verschijnen van het CTW-advies werd dit op hoofdlijnen door het toenmalige kabinet overgenomen ${ }^{61}$ en later werd het belang van de bestuurlijke handhaving in het hoofdlijnenakkoord van het toenmalige kabinet-Balkenende II onderstreept. ${ }^{62}$ Ook in de memorie van toelichting van de Vierde tranche van de Awb werd deze lijn doorgezet. ${ }^{63}$ In de Vierde tranche Awb leidde dat in navolging van het rapport van het CTW-advies tot een afweging aan de hand van diverse afwegingsfactoren, zoals het al dan niet nodig zijn van de vrijheidsstraf, de aard van de normschending (van al dan niet fundamentele waarde), individuele schade of letsel, toepasselijke dwangmiddelen, etc. ${ }^{64}$ Het was volgens de Awb-wetgever aan de bijzondere wetgever om met behulp van deze criteria de keuze te maken voor strafrechtelijke of bestuursrechte-

60. Commissie voor de toetsing van wetgevingsprojecten, Handhaving met bestuurlijke boeten, Advies aan de minister, Den Haag 12 januari 1994.

61. Kamerstukken I/ 1993/94, 23400 VI, nr. 48.

62. Kamerstukken I/ 2002/03, 28 637, nr. 19.

63. Kamerstukken I/ 2003/04, 29 702, nr. 3, p. 117 e.v.

64. Kamerstukken II 2003/04, 29 702, nr. 3, p. 118-119. lijke handhaving of een combinatie van beide. De toepassing van de criteria leidde ertoe dat bij veel wetten werd gekozen voor een combinatie van strafrechtelijke en bestuursrechtelijke handhaving. Enige jaren geleden werd deze discussie verder toegespitst op het door de overheid gehanteerde uitgangspunt van een afweging of de betreffende normstelling een al dan niet specifieke rechtsbetrekking betrof tussen de burger en de overheid. Bij een dergelijke rechtsbetrekking (bijv. het zijn van belastingbetaler of uitkeringsgerechtigde) was dan sprake van een 'gesloten context', in welk geval dan bestuursrechtelijke handhaving de voorkeur had. In een open context zou het strafrecht de voorkeur genieten. ${ }^{65}$

Echter, veel helderheid heeft dat niet gegeven gezien de verschillende wetsvoorstellen met een bestuurlijke boete de afgelopen jaren en de commentaren die daarop zijn verschenen. Het criterium blijkt niet dusdanig eenduidig en bepalend dat helder wordt welk handhavingsstelsel in welk geval de voorkeur verdient. ${ }^{66}$ De laatste jaren werd op dit punt dan ook gepleit voor aanpassing en verheldering van de keuze voor het te volgen sanctiestelsel. ${ }^{67}$ De vraag is echter of die helderheid wel geboden kan worden. Zelfs onze dogmatische oosterburen zijn er na decennia van pogingen niet in geslaagd. ${ }^{68} \mathrm{Wij}$ denken van niet. Om op dit punt een beredeneerd standpunt te kunnen innemen, vergt een brede oriëntatie ten aanzien van beide rechtsgebieden. Het zal naar onze mening inhoudelijk altijd een afweging van diverse deelaspecten blijven, zoals juridische argumenten (als de aard en ernst van de feiten, de frequentie ervan, de maatschappelijk impact, etc.), maar ook niet-juridische afwegingen van effectiviteit (doeltreffendheid, doelmatigheid) en efficiency (kostenbeperkend), afwegingen ten aanzien van de beleidstechnische wensen en de mogelijkheden van de betrokken handhavingsinstanties en ten slotte om afwegingen van politieke haalbaarheid. Desalniettemin denken wij dat op een punt wel degelijk winst is te beha-

65. Zie hierover (gelijke) nota's in: Kamerstukken I 2008/09, 31 700, VI, D en Kamerstukken I/ 2008/09, 31700 VI, nr. 69. Eerder was aan die keuze aandacht geschonken in: Kamerstukken II 1999/2000, 26800 VI, nr. 67, p. 8 en 11; Kamerstukken // 2003/04, 29 279, nr. 9, p. 24 en in de notitie van de minister van Justitie bij de Wet OM-afdoening: Kamerstukken II 2005/06, 29 849, nr. 30. Zie het inzichtelijke artikel toentertijd van Ph. Boer \& D. de Kok, 'Nieuwe keuzes tussen strafrechtelijke en bestuurlijke sancties. Een toelichtende beschouwing bij de kabinetsnota over de uitgangspunten bij de keuze van een sanctiestelsel', NJB 2009, p. 671-676. Zie A.R. Hartmann, Over de grenzen van de dogmatiek en into fuzzy law (oratie Rotterdam), Apeldoorn/Antwerpen: Maklu 2011, p. 39 e.v.

66. Zie in vergelijkbare zin: H.E. Bröring \& B.F. Keulen, Bestraffende sancties in het strafrecht en het bestuursrecht, Zutphen: Paris 2016, p. 21 en 65.

67. Zie voor een overzicht van de recente discussie B. van der Vorm, 'De keuze tussen strafrechtelijke en bestuursrechtelijke sanctionering en het criterium van de ernstige gedraging', Proces 2017, p. 267-280 en N.G.H. Verschaeren, '(Buitengerechtelijke) strafrechtelijke, bestuursrechtelijke, duale of dubbele handhaving?', TPWS 2017, p. 128-136.

68. Vgl. A.R. Hartmann \& P.M. van Russen Groen, Contouren van het bestuursstrafrecht (diss. Rotterdam) deel I, Deventer: Gouda Quint 1998, p. 28-37. Zie ook Daniel Ohara, 'Regulatory Offenses and Administrative Sanctions: between Criminal and Administrative Law', in: Oxford Handbook of Criminal Law, Oxford: OUP 2014, p. 1085-1086. 
len in de huidige situatie bij handhaving via het bestuursrecht en het strafrecht.

Ook de aanbeveling dat er meer eenheid moet zijn bij het bepalen van de boetemaxima en meer afstemming op de geldboetecategorieën in het strafrecht is terecht. De regering had dat dan ook drie jaar eerder al erkend. Dat was echter volgens de Afdeling advisering onvoldoende effectief.

Dat het ministerie van Justitie en Veiligheid meer regie moet voeren op het boetewetgevingsbeleid is een zeer terechte aanbeveling. Het is echter de vraag of de in bezuinigingstijden vormgegeven harde of zelfs draconische SZW-boetesystemen (de Wet BMTI en de Wet Aanscherping en handhaving sanctiebeleid SZW-wetgeving) dan zouden zijn voorkomen, of de veelal door unierecht vereiste hoge omzet-gerelateerde bestuurlijke boetes (in het financiële bestuursrecht en de AVG) niet in onze rechtsorde zouden zijn en worden geïntroduceerd. Ook vragen we ons af of daarmee het boetestelsel van de Wet dieren zou zijn voorkomen op grond waarvan de kenbaarheid van het beboetbare feit zo gering is dat te grote spanning met het rechtszekerheidsbeginsel is ontstaan. En is dat ministerie van Justitie niet verantwoordelijk voor de introductie van een strafbeschikking naast het boetewetgevingsbeleid dat op forse uitbreiding van de boetebevoegdheden is gericht?

\section{Regeringsstandpunt}

In een eerste reactie van 8 januari $2016^{69}$ onderschrijft de regering de opvatting van de Afdeling advisering dat de bestuurlijke boete 'niet meer weg te denken is als handhavingsinstrument en zich een volwaardige plaats heeft verworven in ons handhavingsbestel.' De regering vervolgt terecht:

'Het signaal dat er meer aandacht moet zijn voor de verschillen in rechtsbescherming en rechtspositie van de justitiabele tussen het strafrecht en het bestuursrecht, te meer daar het strafrecht in de strafbeschikking een nieume buitengerechtelijke afdoeningsmodaliteit kent, neem ik serieus. Voorts onderschrijf ik de gedachte dat bij beboeting niet alleen efficiencyovermegingen ten grondslag behoren te liggen aan de keuze voor een bepaald sanctiestelsel (bestuursrechtelijk, strafrechtelijk dan wel in bepaalde gevallen een combinatie van beide rechtsgebieden). Het is belangrijk te bezien of en in hoeverre, in het licht van de geschetste ontwikkelingen, aanscherping of aanvulling van de verschillende eerder genoemde criteria die ten grondslag liggen aan de keuze voor een punitief handhavingsstelsel, aangemezen is.' (p.2)

Ook plaatst de regering terecht vraagtekens bij het oordeel van de Afdeling advisering over de verschillen in rechtswaarborgen en rechtsbescherming. Vervolgens werd een interdepartementale werkgroep in het leven geroepen om eens goed op het onderwerp te kauwen. De bevindingen van die werkgroep werden als lijvig nader

69. Kamerstukken I/ 2015/16, 34300 VI, nr. 72. rapport gepresenteerd op 14 mei $2018 .^{70}$ De kern daarvan is dat meer aandacht komt voor de eenheid bij het bepalen van de hoogte van de bestuurlijke boete. Het gaat de regering om het verantwoorden van een boetestelsel jegens de burger. De evenredigheid is daarvan kern. Er is bijsturing nodig om draagvlak te behouden. Ook wordt nu eenvoudigweg erkend dat het precies afbakenen van het strafrechtelijke en het bestuursrechtelijke bestraffende systeem niet mogelijk is. De regering schrijft:

'Het kabinet constateert dat er ook geen nieum algemeen geldend kmalitatief onderscheidend criterium is gevonden op grond maarvan in de toekomst de keuze voor punitief bestuursrechtelijke respectievelijk strafrechtelijke handhaving in dat grijze gebied wel helder gemaakt kan worden (laat staan dwingend pordt voorgeschreven). Het kabinet kiest ervoor om de open of besloten context niet meer als uitgangspunt te nemen bij de keuze tussen sanctiestelsels. In plaats daarvan zal voortaan de keuze voor een bepaald sanctiestelsel aan de hand van álle relevante, reeds bekende, (contra-)indicatoren en criteria uit de verschillende kabinetsnota's (maaronder ook het open of besloten context-criterium) moeten morden beoordeeld en dragend onderboumd.' (p. 8)

De regering stelt voor om in de Awb te verankeren dat de maximum bestuurlijke boete wordt afgestemd op de geldboetecategorieën uit artikel $23 \mathrm{Sr}$. Ook zullen bestaande boetestelsels worden aangepast aan de nieuwe regels over de afstemming van maxima. We vermoeden dat het in de Awb verankeren van de regel dat in een duaal stelsel het boetemaximum niet hoger mag zijn dan het strafrechtelijke geldboetemaximum te rigide zou kunnen zijn. Het spreekt vanzelf dat het Openbaar Ministerie en boetebevoegde bestuursorganen bij bestaande duale stelsels overleg voeren over elkaars beleid om tot vervolging of beboeting over te gaan. Echter, het eisen van afstemming (en dat is meer dan overleg) bij het requireerbeleid en het beleid over de hoogte van de bestuurlijke boete lijkt ons erg ver gaan. Het door de regering in het nader rapport aangekondigde onderzoek naar de voor- en nadelen van schorsende werking in de bezwaarfase is inmiddels gepubliceerd. ${ }^{71}$ We verwachten dat dit ook tot wetswijziging zal leiden, en dat is terecht.

\section{Wat moet er nog meer gebeuren?}

Er is uiteindelijk naar anleiding van het advies van de Afdeling advisering terecht veel aandacht besteed aan de hoogte van de boetemaxima en de onderlinge afstemming daarvan. Ook heeft de door de wetgever na te stre-

70. Kamerstukken // 2017/18, 34775 VI, nr. 102.

71. H.E. Bröring e.a., 'Schorsende werking van rechtsmiddelen bij bestuurlijke boetes', WODC 2020 
ven evenredigheid stellig meer aandacht gekregen in het nader rapport. Het valt ons echter op dat er vrij weinig aandacht werd en wordt besteed aan de samenloop van sancties en het stapelen van beboetbaarstellingen en strafbaarstellingen in duale stelsels. Het gaat hier om de beslissing van de wetgever die voorafgaat aan het kiezen van het boete- of strafmaximum.

Juist nu - overigens terecht - wordt afgezien van het zoeken naar een onderscheidend criterium bij de keuze om een feit strafbaar of beboetbaar te stellen, dreigt nog meer te worden gekozen voor de meest eenvoudige wetgevingsoplossing: het duale stelsel waarin de bestraffing van ongewenste gedragingen in beide systemen worden ondergebracht. Juist omdat de bestuurlijke boete een volwaardige bestraffende sanctie in handen van het gespecialiseerde bestuur is, zou beboetbaar stellen regel moeten zijn en het toevoegen van nieuwe strafbaarstellingen strikte uitzondering. Het aantal duale stelsels zou dienen te worden teruggedrongen. Er kan in de gevallen dat het echt fout zit altijd worden teruggevallen op de commune delicten waarbij de ruime reikwijdte van delicten als valsheid in geschrift, oplichting, heling, witwassen en het deelnemen aan een criminele organisatie, er zeker voor kan zorgen dat feiten die tot de betreffende achterliggende rechtsgoederen hebben geschaad, kunnen worden aangepakt. Dat is volgens ons de invulling van het voorgestane optimum remedium dat inmiddels zijn intreden heeft gedaan. ${ }^{72}$

We wijzen erop dat het wetgevingsbeleid volgens hetwelk strafbaarstellingen en beboetbaarstellingen cumuleren en de wetgever vertrouwt op correctie door de rechter, de Hoge Raad ertoe bracht om het werkingsbereik van eendaadse samenloop en voortgezette handeling te verruimen. De Hoge Raad overwoog in de betreffende verduidelijkingsarresten ${ }^{73}$ immers:

'dat ook de metgever zich ervan bemust is dat recente petgeving aanleiding geeft tot zorg over dubbele bestraffing en dat tegen die zorg wordt ingebracht dat de samenloopregeling maarborgen en oplossingen biedt. Dat betekent dat de samenloopregeling - en dan meer in het bijzonder de eendaadse samenloop en de voortgezette handeling - daarvoor ook daadwerkelijk voldoende ruimte moet bieden.'

De bestuursrechter verruimde het instrumentarium om op grond van het evenredigheidsbeginsel cumulatie nog verder terug te dringen met de matiging in gevallen waarin op zichzelf genomen geen sprake is van eendaadse samenloop, maar waar van zodanige samenhang

72. Vgl. L.J.J. Rogier, Bestuursrecht of strafrecht. Instrumentaliteit of moraliteit? (Afscheidsrede Rotterdam), Den Haag: Boom Juridische uitgevers 2014; B. van der Vorm, 'Bespiegelingen over de keuze tussen bestuursrecht en strafrecht', RegelMaat 2017, p. 336-348; M. Hirsch Ballin, Over grenzen bij bewijsvergaring. Grondslagen voor geïntegreerde normering van strafrechtelijke bewijsvergaring (oratie Amsterdam VU), Den Haag: Boom juridisch 2018; en S.S. Buisman, 'Criteria voor strafbaarstelling', BSb 2020, nr. 1, p. 64-72.

73. HR 20 juni 2017, ECLI:NL:HR:2017:1111-1115 tussen twee of meer gedragingen sprake is dat het onevenredig is om beide overtredingen afzonderlijk te beboeten. $^{74}$

De regering stelt terecht voor om de Awb-boeteregeling aan te vullen met een regeling waarin de maxima voor de bestuurlijke boete worden afgestemd op de geldboetecategorieën in artikel $23 \mathrm{Sr}$. Ook verwachten we dat de schorsende werking van bezwaar als hoofdregel wordt ingevoerd in de Awb. Op deze wijze wordt de 'harmonisatiekracht' van die regeling vergroot. Ook op een ander punt zou deze kunnen worden vergroot, te weten door het onderscheid tussen een lichte (die vrijwel nooit voortkomt) ${ }^{75}$ lichte zware, middelzware zware en zware procedure zichtbaar te maken. ${ }^{76}$

\section{De afronding}

In het voorgaande hebben we in reactie op het advies van de Afdeling advisering van de Raad van State van 2015 en de daaropvolgende reactie van de regering van mei 2018 onze kijk gegeven op enkele punten. Wij zijn ervan overtuigd dat er nog heel veel tijd overheen gaat voordat op de verschillende aangehaalde onderdelen, een daadwerkelijke aanpassing van wetgeving zal volgen. Wij zien in het bijzonder in de verbetering in de afstemming van de boetehoogtes tussen het bestuursrecht en het strafrecht nog echt een hersenkraker hoe dat op te lossen. Ook een keuze voor een adequaat onderscheidend criterium voor de keuze tussen beide handhavingsstelsels is blijkens de discussies van de afgelopen jaren op dat punt een gordiaanse knoop gebleken.

Wat ons betreft is de vaststelling onvermijdelijk dat de bestuurlijke boete een algemene, en veel voorkomende bestraffende sanctie in handen van het bestuur is. Het is 'normaal' geworden dat ook niet-justitiële bestuursorganen mogen bestraffen (met de bestuurlijke boete). Immers, ook op beleidsterreinen waar de bestuurlijke boete nu nog niet beschikbaar is om overtredingen te bestraffen die zeer vergelijkbaar zijn met overtredingen die op andere beleidsterreinen reeds beboetbaar zijn gesteld, gaat de bestuurlijke boete ingevoerd worden. Indien niet vandaag, dan wel morgen. Het is wat ons betreft veel vruchtbaarder om die werkelijkheid als uitgangspunt te nemen bij de vraag wat de rol van het strafrecht bij de bestraffende handhaving is.

Daarbij staat voor ons vast dat veel serieuzer dient te worden gekeken of het uitgangspunt van de duale hand-

74. Zie bijvoorbeeld ABRvS 11 april 2018, ECLI:NL:RVS:2018:1217

75. We doelen hier op de boeteregeling waarvoor op grond van artikel 5:53 Awb de lichtste procedure geldt (zonder hoorplicht en functiescheiding). Het gaat daarbij om procedures die kunnen leiden tot bestuurlijke boetes van meer dan $€ 340$ (ook dit bedrag zou op een geldboetecategorie moeten worden afgestemd) of indien de bijzondere regelgever dat bepaalt.

76. Zie O.J.D.M.L. Jansen, 'Bestuurlijk en justitieel bestraffen in Nederland op zoek naar (nog) meer eenheid', in: R.C. van Houten (red.), a.w., p. 46. 
having niet veel rigoureuzer op de schop moet worden genomen. Een begin met een keuze voor bestuursrechtelijke handhaving en bestraffing als uitgangspunt van (met name: ordenings-)wetgeving met in het achterhoofd de immer bestaande, eventuele mogelijkheid van strafrechtelijke vervolging voor commune delicten, vormt tenminste een veel helderder uitgangspunt voor de publiekrechtelijke rechtshandhaving. 